Mongolian Academy of Sciences
Mongolian Journal of Chemistry
The Institute of Chemistry \& Chemical Technology

\title{
The main chemical properties of hot and cold mineral waters in Bayankhongor, Mongolia
}

\author{
D. Oyuntsetseg ${ }^{1,3^{*}}$, E. Uugangerel ${ }^{2}$, A.Minjigmaa $^{1}$ and A. Ueda ${ }^{3}$ \\ ${ }^{1}$ Institute of Chemistry and Chemical Technology, MAS, Peace ave., Ulaanbaatar 13330, Mongolia \\ ${ }^{2}$ School of Engineering and Applied Sciences, National University of Mongolia, str. University 1 , \\ 14201, Ulaanbaatar, Mongolia \\ ${ }^{3}$ Graduate School Divisions of Science and Engineering, University of Toyama, \\ Gofuku 3190, 930-8555, Japan
}

ARTICLE INFO: Received 03 November 2014; revised 14 November 2014; accepted 20 November 2014

\begin{abstract}
In the current study, hot and cold mineral springs and sub mineral waters in the Bayankhongor province were examined for their chemical characteristics and identified cold mineral waters classification according to mineral water classification of Mongolia. The hot spring waters belong to $\mathrm{Na}^{+}-\mathrm{HCO}_{3}{ }^{-}$and $\mathrm{Na}^{+}-\mathrm{SO}_{4}{ }^{2-}$ types. The cold mineral spring of $\mathrm{Lkham}$ belongs to $\mathrm{Ca}^{2+}-\mathrm{HCO}_{3}{ }^{-}$type. All sub mineral waters are generally located in the two areas (northern part or mountain forest area and the southern part or Gobi desert area). TDS concentrations of cold springs of the southern part in the study area were higher than northern part's cold springs. The total dissolved silica content of cold spring was ranged from $4.5 \mathrm{mg} / \mathrm{L}$ to $26 \mathrm{mg} / \mathrm{L}$ which did not correspond to requirements of mineral water standard of Mongolia. Thus, these cold springs are belonging to sub mineral water classification. The sub mineral waters were characterized into four types such as a $\mathrm{Ca}^{2+}-\mathrm{SO}_{4}{ }^{2-}, \mathrm{Na}^{+}-\mathrm{SO}_{4}{ }^{2-}, \mathrm{Na}^{+}-\mathrm{HCO}_{3}$ and $\mathrm{Ca}^{2+}-\mathrm{HCO}_{3}$ by their chemical composition in the study area. The values for the quartz, chalcedony geothermometer and the $\mathrm{Na} / \mathrm{K}$ geothermometer were quite different. The silica-enthalpy mixing model predicts a subsurface reservoir temperature between 124 and $197^{\circ} \mathrm{C}$ and most of the hot waters have been probably mixed with cold water. The result shows that an averaged value of calculated temperature ranges from $77^{\circ} \mathrm{C}$ to $119^{\circ} \mathrm{C}$ which indicates that studied area has low temperature geothermal resources.
\end{abstract}

Keywords: hot and cold mineral waters, chemical composition, Bayankhongor, Mongolia

\section{INTRODUCTION}

Mongolia consists of 21 provinces and Bayankhongor province is located in the southwestern part of the country and area covers 116,000 square kilometers. It is one of the largest provinces in Mongolia. The Bayankhongor province includes very diverse geographic areas. It is typically divided into three areas: the northern part belongs to mountain forest, the central part belongs to steppe and the southern part belongs to Gobi desert [3]. Hot and cold mineral waters are mainly distributed in the northern part of the Bayankhongor province (Khangai mountain area). Mongolians have used hot springs for many centuries, for bathing and small scale heating, as well as agricultural and medicinal purposes (e.g. treatment of high blood pressure, rheumatism, disease of the nervous system etc. using geothermal water). The first systematical study of hot mineral waters of Bayankhongor province was performed by Smirnov et al. during 1926-1927. Further more detailed investigation on the formation of mineral water, their distribution and chemical composition were studied by Marinov, Namnandorj $[12,13]$ etc. The monographs on mineral water resources of Mongolia were published in 1963 and 1966. Mongolia and Soviet Union's joint hydrochemical Khubsgul research group was performed research on complex study of hydromineral resources in Mongolia during 19761980.

Based on all previous research The map of Mineral springs of Mongolia were created in 1983. According to the results of many years of studies it has been established that Bayankhongor province has about 5 hot waters. The most investigated one is Shargaljuut hot spring and it's $54 \mathrm{~km}$ far from the Bayankhongor province center. The Shargaljuut hot spring consists of about 100 individual hot springs with temperature ranges from $45^{\circ} \mathrm{C}$ to $95^{\circ} \mathrm{C}$.

Previous studies have determined chemical composition in hot springs of Bayankhongor province $[2,10]$. They concluded that the hot springs are

*corresponding author: e-mail: oyuntsetsegdj@yahoo.com

DOI: http://doi.dx.org/10.5564/mjc.v15i0.324 
belong to $\mathrm{Na}^{+}-\mathrm{HCO}_{3}$ and $\mathrm{Na}^{+}-\mathrm{HCO}_{3}, \mathrm{SO}_{4}$ types. Isotopic study of hot springs in Bayankhongor province had done from 2012 to 2013 and concluded that the geothermal waters originate in the local meteoric waters [5].

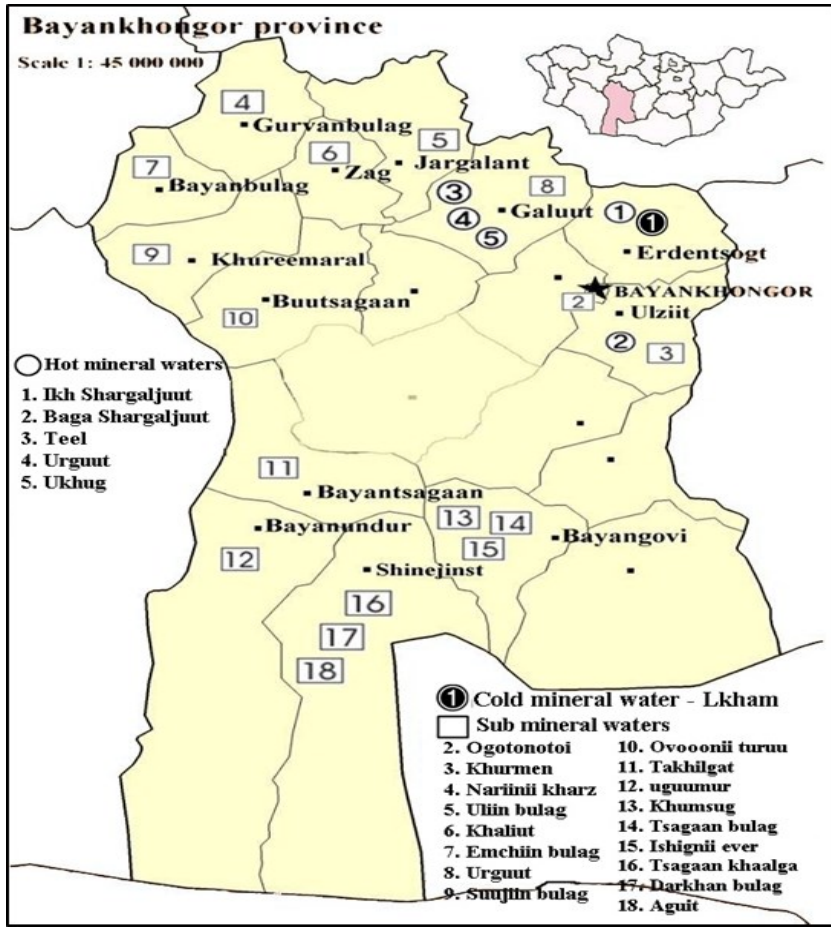

Fig. 1. Sample locality of hot and cold spring waters in the study area

Table 1. Sample locality in the study area

\begin{tabular}{|c|c|c|c|c|c|c|c|c|c|}
\hline No & Sample type & Mineral waters & Latitude & Longitude & Altitude (m) & Temperature, ${ }^{\circ} \mathrm{C}$ & $\mathrm{pH}$ & $\mathrm{EC}, \mathrm{mS} / \mathrm{m}$ & ORP, mV \\
\hline 1 & & Ikh Shargaljuut & $46^{\circ} 19^{\prime} 57.7$ & $101^{\circ} 13^{\prime} 29.4$ & 2150 & 95 & 9.6 & 37.1 & 315 \\
\hline 2 & & Baga Shargaljuut & $46^{\circ} 14^{\prime} 02.4$ & $101^{\circ} 09^{\prime} 11.8$ & 2057 & 57 & 9.5 & 37.1 & 394 \\
\hline 3 & Hot mineral & Teel & $46^{\circ} 51^{\prime \prime} 43.4$ & $100^{\circ} 06^{\prime} 56.4$ & 2112 & 32 & 9.7 & 28.3 & 177 \\
\hline 4 & & Urguut & $46^{\circ} 33^{\prime} 54.3$ & $100^{\circ} 24^{\prime} 09.9$ & 2330 & 42 & 8.4 & 44 & 80 \\
\hline 5 & & Ukhug & $46^{\circ} 47^{\prime} 59.9$ & $100^{\circ} 25^{\prime} 53.8$ & 2377 & 58 & 9.5 & 47.4 & 234 \\
\hline 6 & $\begin{array}{c}\text { Cold mineral } \\
\text { water }\end{array}$ & Lkham & $46^{\circ} 20^{\prime} 03.5$ & $101^{\circ} 13^{\prime} 38.3$ & 2131 & 14 & 7.5 & 38.8 & 328 \\
\hline 7 & & Ogotonotoi & $46^{\circ} 11^{\prime} 25.1$ & $100^{\circ} 43^{\prime} 57.9$ & 1870 & $<10$ & 7.4 & 34.3 & 382 \\
\hline 8 & & Khurmen & $45^{\circ} 41^{\prime} 24.9$ & $101^{\circ} 02^{\prime} 30.5$ & 1898 & $<15$ & 7.9 & 92.1 & 181 \\
\hline 9 & & Nariinii kharz & $47^{\circ} 24^{\prime} 23.7$ & $98^{\circ} 35^{\prime} 12.1$ & 2505 & $<15$ & 7.6 & 23 & 402 \\
\hline 10 & & Uliin bulag & $47^{\circ} 03^{\prime} 37.3$ & $99^{\circ} 42^{\prime} 50.6$ & 2264 & $<15$ & 7.8 & 25.5 & 408 \\
\hline 11 & & Khaliut & $46^{\circ} 46^{\prime} 19.3$ & $99^{\circ} 19^{\prime} 03.3$ & 1908 & 5 & 7.6 & 63.2 & 392 \\
\hline 12 & & Emchiin bulag & $46^{\circ} 53^{\prime} 20.3$ & $97^{\circ} 57^{\prime} 40.2$ & 2677 & $<15$ & 7.7 & 40.3 & 417 \\
\hline 13 & & Urguut & $46^{\circ} 48^{\prime} 03.1$ & $100^{\circ} 25^{\prime} 58.5$ & 2374 & 5 & 7.4 & 31.5 & 277 \\
\hline 14 & Sub mineral & Suujiin bulag & $47^{\circ} 06^{\prime} 58.9$ & $99^{\circ} 43^{\prime} 37.8$ & 2278 & $<15$ & 7.9 & 97.4 & 417 \\
\hline 15 & waters & Ovoonii turuu & $46^{\circ} 18^{\prime} 10.6$ & $98^{\circ} 51^{\prime} 12.6$ & 2102 & $<15$ & 7.9 & 44.7 & 414 \\
\hline 16 & & Takhilgat & $45^{\circ} 08^{\prime} 26.5$ & $98^{\circ} 47^{\prime} 08.8$ & 2000 & $<15$ & 7.8 & 94.2 & 434 \\
\hline 17 & & Uguumur & $44^{\circ} 45^{\prime} 02.8$ & $98^{\circ} 23^{\prime} 04.2$ & 1982 & $<15$ & 7.9 & 105 & 420 \\
\hline 18 & & Khumsug & $44^{\circ} 46^{\prime} 30$ & $100^{\circ} 34^{\prime} 43.3$ & 1813 & $<15$ & 7.7 & 11.9 & 290 \\
\hline 19 & & Tsagaan bulag & $44^{\circ} 36^{\prime} 10.6$ & $100^{\circ} 20^{\prime} 50.8$ & 1506 & $<15$ & 7.5 & 113 & 287 \\
\hline 20 & & Ishignii ever & $44^{\circ} 21^{\prime} 39.9$ & $99^{\circ} 58^{\prime} 039$ & 2109 & $<15$ & 7.4 & 60.2 & 284 \\
\hline 21 & & Tsagaan khaalga & $44^{\circ} 25^{\prime} 22.3$ & $99^{\circ} 18^{\prime} 59.2$ & 1328 & $<15$ & 8.0 & 60.7 & 318 \\
\hline 22 & & Darkhan bulag & $44^{\circ} 30^{\prime} 26.9$ & $98^{\circ} 02^{\prime} 01.6$ & 2022 & $<15$ & 7.6 & 62.4 & 328 \\
\hline 23 & & Aguit & $44^{\circ} 17^{\prime} 52.2$ & $99^{\circ} 27^{\prime} 17.8$ & 2113 & $<15$ & 6.6 & 17.7 & 388 \\
\hline
\end{tabular}

Detailed investigation of the cold mineral waters in Bayankhongor province has not been carried out. Aim of this study is to determine chemical characterization of the hot and cold mineral waters in Bayankhongor province and to identify cold mineral waters classification using the mineral water classification of Mongolia. 
August, 2013 from Bayankhongor province in Mongolia Figure 1 and Table 1.

The analyses were carried out both in the field and in the laboratory. At the sampling site, spring samples were collected into $1000 \mathrm{ml}$ plastic bottles for subsequent chemical analysis that was made by flame photometer and standard methods in laboratory. Water temperature, $\mathrm{pH}, \mathrm{EC}$ and ORP were measured by digital thermometer, a pH meter (TOA, HM-30P), EC meter (TOA, CM-31P) and ORP meter (TOA, RM$30 \mathrm{P})$, respectively. Major cation concentrations $\left(\mathrm{Ca}^{2+}\right.$, $\mathrm{Mg}^{2+}$ ) were determined by trilon-B titration whereas $\mathrm{Na}^{+}$and $\mathrm{K}^{+}$were determined by inductively coupled plasma optical emission spectrometry. The anions of $\mathrm{HCO}_{3}{ }^{-}, \mathrm{Cl}^{-}$and $\mathrm{SO}_{4}{ }^{2-}$ were determined by $0.1 \mathrm{~N} \mathrm{HCl}$ titration, $0.1 \mathrm{~N} \mathrm{AgNO}_{3}$ titration and weight balance method, respectively. Dissolved silica was determined by molybdenum yellow method using a spectrophotometer (S2100 UV Spectrophotometer, Cole Parmer) and minor components $\left(\mathrm{NH}_{4}, \mathrm{Fe}, \mathrm{NO}_{2}\right.$ and $\mathrm{NO}_{3}$ ) were determined by spectrophotometer. The total dissolved solid content was determined by evaporating 1 litre of filtered water sample at $100^{\circ} \mathrm{C}$. Eventually, the residue was dried at $180^{\circ} \mathrm{C}$ for 2 hours. Analyses of major and minor compositions were carried out at the geochemical laboratory of the Institute of Chemistry and Chemical Technology of the Mongolian Academy of Science. The results of the chemical analysis of hot and cold springs from the Bayankhongor province in Mongolia are presented in Table 2.

\section{RESULTS AND DISCUSSION}

Chemical composition: The descriptions of sampling locations and geochemical results of hot and cold waters are listed in Tables 1 and 2 . The discharge temperature of hot springs varied from $32 \mathrm{C}$ to $95^{\circ} \mathrm{C}$ while their $\mathrm{pH}$ varied from 8.4 to 9.7 which indicates alkaline characteristics. The electric conductivity (EC) of hot springs varied from $28 \mathrm{mS} / \mathrm{m}$ to $47 \mathrm{~ms} / \mathrm{m}$. The sodium cation is dominating in the hot springs (Table 2) ranging from $71 \mathrm{mg} / \mathrm{L}$ to $105 \mathrm{mg} / \mathrm{L}$ while the other cation concentrations such as those of $\mathrm{K}^{+}, \mathrm{Ca}^{2+}$ and $\mathrm{Mg}^{2+}$ are very low. Total alkalinity values $\left(\mathrm{HCO}_{3}{ }^{-}\right)$is the dominant anion revealed up to $170 \mathrm{mg} / \mathrm{L}$ while chloride concentrations are below $26 \mathrm{mg} / \mathrm{L}$ and sulfate concentrations range from $25 \mathrm{mg} / \mathrm{L}$ to $49 \mathrm{mg} / \mathrm{L}$. The sulfate concentration of Ukheg hot spring (sample №5) is higher than other hot springs. The total dissolved silica content of hot springs ranged from $45 \mathrm{mg} / \mathrm{L}$ to $104 \mathrm{mg} / \mathrm{L}$. Total dissolved solids (TDS) concentration were ranged from 210 to $326 \mathrm{mg} / \mathrm{L}$.

The bicarbonate $\left(\mathrm{HCO}_{3}\right)$ concentration of Lkham cold spring (Table 2; sample №6) is dominant cation ranges from $98 \mathrm{mg} / \mathrm{L}$ to $228 \mathrm{mg} / \mathrm{L}$ and dominant anions were $\mathrm{Ca}^{2+}$ (36 mg/L) and $\mathrm{Na}(36 \mathrm{mg} / \mathrm{L})$.

Total dissolved solids (TDS) concentration ( $265 \mathrm{mg} / \mathrm{L}$ ) was lower than that of the other cold springs. The total dissolved silica content of Lkham cold spring was $56 \mathrm{mg} / \mathrm{L}$ that correspond to requirements of mineral water standard of Mongolia. Therefore, cold spring of Lkam is belonging into cold mineral water classification.

Table 2. Chemical composition of water samples in the study area.

\begin{tabular}{|c|c|c|c|c|c|c|c|c|c|c|c|c|c|c|}
\hline № & Sample type & Mineral waters & $\begin{array}{r}\mathrm{Na}+\mathrm{K} \\
\mathrm{mg} / \mathrm{l}\end{array}$ & $\mathrm{Ca}$ & $\mathrm{Mg}$ & $\mathrm{NH}_{4}$ & $\mathrm{Fe}_{\text {total }}$ & $\mathrm{Cl}$ & $\mathrm{SO}_{4}$ & $\mathrm{HCO}_{3}$ & $\mathrm{NO}_{2}$ & $\mathrm{NO}_{3}$ & $\mathrm{SiO}_{2}$ & TDS \\
\hline 1 & \multirow{5}{*}{$\begin{array}{l}\text { Hot mineral } \\
\text { waters }\end{array}$} & Ikh Shargaljuut & 83 & 3.2 & 0.5 & - & - & 26 & 33 & 97 & - & - & 104 & 243 \\
\hline 2 & & Baga Shargaljuut & 84 & 2.4 & 0.5 & - & - & 13 & 49 & 97 & - & - & 84 & 246 \\
\hline 3 & & Teel & 71 & 3.2 & 0.5 & - & - & 13 & 25 & 97 & 0 & 0.4 & 45 & 210 \\
\hline 4 & & Urguut & 105 & 4.8 & 0.4 & - & - & 14 & 42 & 170 & & & 59 & 326 \\
\hline 5 & & Ukhug & 104 & 7.2 & 0.5 & - & - & 26 & 66 & 121 & - & 0.1 & 99 & 325 \\
\hline 6 & \multirow[t]{8}{*}{$\begin{array}{l}\text { Cold mineral } \\
\text { water }\end{array}$} & Lkham & 36.1 & 36.1 & 4.9 & - & - & 40 & 49 & 98 & - & 1.7 & 56 & 265 \\
\hline 7 & & Ogotonotoi & 44 & 28 & 4.9 & 0.1 & - & 40 & 8.2 & 146 & 0 & 1.2 & 11 & 272 \\
\hline 8 & & Khurmen & 89 & 44 & 39 & 0.5 & - & 66 & 115 & 293 & 0.23 & 15 & 25 & 661 \\
\hline 9 & & Nariinii kharz & 30 & 16 & 4.9 & 0.1 & 0.02 & 26 & 8.2 & 98 & 0.01 & 0.4 & 10 & 184 \\
\hline 10 & & Uliin bulag & 57 & 16 & 7.3 & - & 0.07 & 13 & 33 & 171 & 0.01 & 0.9 & 26 & 298 \\
\hline 11 & & Khaliut & 52 & 64 & 29 & - & 0.01 & 53 & 91 & 268 & 0.01 & 6.8 & 12 & 564 \\
\hline 12 & & Emchiin bulag & 55 & 52 & 4.4 & 0.8 & 0.11 & 40 & 33 & 220 & 0.01 & 0.1 & 19 & 405 \\
\hline 13 & & Urguut & 44 & 48 & 9.7 & - & 0.01 & 26 & 16 & 244 & 0 & 1.4 & 16 & 390 \\
\hline 14 & \multirow{10}{*}{$\begin{array}{l}\text { Sub mineral } \\
\text { waters }\end{array}$} & Suujiin bulag & 143 & 56 & 29 & 0.2 & - & 66 & 189 & 342 & 0.01 & 0.5 & 18 & 825 \\
\hline 15 & & Ovoonii turuu & 66 & 40 & 9.7 & 0.1 & - & 26 & 41 & 244 & - & 4.1 & 22 & 431 \\
\hline 16 & & Takhilgat & 96 & 56 & 39 & 0.6 & 0.01 & 40 & 165 & 342 & - & 3.9 & 4.5 & 742 \\
\hline 17 & & Uguumur & 130 & 88 & 29 & 0.5 & 0.02 & 80 & 296 & 244 & - & 3.1 & 9.4 & 871 \\
\hline 18 & & Khumsug & 44 & 64 & 41 & 0.1 & - & 27 & 156 & 268 & 0.003 & 7.9 & 5.2 & 609 \\
\hline 19 & & Tsagaan bulag & 164 & 64 & 22 & 0.2 & - & 40 & 370 & 195 & - & 6.8 & 5.3 & 863 \\
\hline 20 & & Ishignii ever & 32 & 80 & 19 & 0.1 & - & 53 & 82 & 220 & 0.19 & 11 & 6.3 & 498 \\
\hline 21 & & Tsagaan khaalga & 60 & 48 & 15 & 0.3 & - & 40 & 66 & 220 & 0.02 & 7.5 & 11 & 456 \\
\hline 22 & & Darkhan bulag & 77 & 72 & 9.7 & 0.0 & - & 53 & 99 & 244 & 0.03 & 11 & 19 & 566 \\
\hline 23 & & Aguit & 30 & 12 & 7.3 & 0.2 & - & 26 & 8.2 & 97.6 & 0.06 & 1.1 & 10 & 183 \\
\hline
\end{tabular}


The water temperatures of cold spring waters range from 5 to $15^{\circ} \mathrm{C}$ and the $\mathrm{pH}$ values range from 6.6 to 8.0. The electric conductivity (EC) of cold spring waters range from $17 \mathrm{mS} / \mathrm{cm}$ to $97 \mathrm{mS} / \mathrm{cm}$ Table 1 . All cold springs are located in the two areas (northern part or mountain forest area and the southern part or Gobi desert area). The sodium concentration of cold springs (Table 2; sample № 7-15 and Figure 1; 2-10) in northern part of Bayankhongor province are dominant cation range from $30 \mathrm{mg} / \mathrm{L}$ to $143 \mathrm{mg} / \mathrm{L}$ except one cold spring (Table 2; sample №13 and dominant cation is $\mathrm{Ca}(48 \mathrm{mg} / \mathrm{L}))$ and $\mathrm{Ca}$ concentrations values range from 16 to $64 \mathrm{mg} / \mathrm{l}$ and $\mathrm{Mg}$ concentrations range from $4.4 \mathrm{mg} / \mathrm{L}$ to $39 \mathrm{mg} / \mathrm{L}$, respectively. Total alkalinity values $\left(\mathrm{HCO}_{3}{ }^{-}\right)$is the dominant anion ranges from $32 \mathrm{mg} / \mathrm{L}$ to $342 \mathrm{mg} / \mathrm{L}$, and chloride concentrations ranges from $13 \mathrm{mg} / \mathrm{L}$ to $66 \mathrm{mg} / \mathrm{L}$. Sulfate concentrations range from $8.2 \mathrm{mg} / \mathrm{L}$ to $189 \mathrm{mg} / \mathrm{L}$. Total dissolved solids (TDS) concentration was range from 184 to $564 \mathrm{mg} / \mathrm{L}$ except sample №14 (825 mg/L, Table 2).

The sodium is dominated cation in cold springs (Table 2; sample №16-23 and Figure 1 ; 11-18) of the southern part of Bayankhongor province and it ranges from $30 \mathrm{mg} / \mathrm{L}$ to $164 \mathrm{mg} / \mathrm{L}$ except two cold spring (Table 2; sample №18 and 20 and dominant cation is $\mathrm{Ca}(64 \mathrm{mg} / \mathrm{L})$ and $80 \mathrm{mg} / \mathrm{L})$ and $\mathrm{Ca}$ concentrations range from 12 to $88 \mathrm{mg} / \mathrm{l}$ and $\mathrm{Mg}$ concentrations range from $7.3 \mathrm{mg} / \mathrm{L}$ to $41 \mathrm{mg} / \mathrm{L}$, respectively. Total alkalinity values $\left(\mathrm{HCO}_{3}{ }^{-}\right)$is the dominant anion and it ranges from $97 \mathrm{mg} / \mathrm{L}$ and $342 \mathrm{mg} / \mathrm{L}$ except for two cold spring (Table 2; sample № 18 and 19 and dominant anion is $\mathrm{SO}_{4}(296 \mathrm{mg} / \mathrm{L}$ and $\left.379 \mathrm{mg} / \mathrm{L})\right)$. The chloride concentrations range from $26 \mathrm{mg} / \mathrm{L}$ to 53 $\mathrm{mg} / \mathrm{L}$. The sulfate concentrations range between 8.2 $\mathrm{mg} / \mathrm{L}$ to $165 \mathrm{mg} / \mathrm{L}$. Total dissolved solids (TDS) concentration are between 456 and $871 \mathrm{mg} / \mathrm{L}$ except for sample №23 (183 mg/L) in Table 2 .

TDS concentrations of cold springs of the southern part in the study area were higher than cold springs of the northern part in the study area. The total dissolved silica content of cold spring is ranging from $4.5 \mathrm{mg} / \mathrm{L}$ to $26 \mathrm{mg} / \mathrm{L}$ which did not correspond to requirements of mineral water standard of Mongolia. Therefore, those cold springs are belonging into classification of sub mineral water.

The Piper diagram for the water samples in the study area are shown in Figure 2. All hot springs in the study area belong to $\mathrm{Na}^{+}-\mathrm{HCO}_{3}{ }^{-}$type except one hot spring $\left(\mathrm{Na}^{+}-\mathrm{HCO}_{3}, \mathrm{SO}_{4}{ }^{2-}\right.$ type; sample №.5). The cold mineral spring of Lkham belong to $\mathrm{Ca}^{2+}-\mathrm{HCO}_{3}{ }^{-}$ type. The chemical composition of the sub mineral waters in the study area were characterized into four types. The sub mineral water of Uguumur (sample №17) belongs to $\mathrm{Ca}^{2+}-\mathrm{SO}_{4}{ }^{2-}$ type and sample №19 belongs to $\mathrm{Na}^{+}-\mathrm{SO}_{4}{ }^{2-}$ type. The sub mineral waters (sample № 7, 10, 14, 15 and 16) belongs to $\mathrm{Na}^{+}-\mathrm{HCO}_{3}$ type and other sub mineral waters are belong to $\mathrm{Ca}^{2+}$ $-\mathrm{HCO}_{3}$ type, respectively.
The relationship between $\mathrm{Ca}^{2+}+\mathrm{Mg}^{2+}$ and $\mathrm{HCO}^{-}$ concentrations is shown in Figure 3 , where the broken line corresponds to the ion exchange of $\mathrm{Ca}^{2+}$ $+\mathrm{Mg}^{2+}$ with $\mathrm{Na}^{+}+\mathrm{K}^{+}$following the reaction with clay

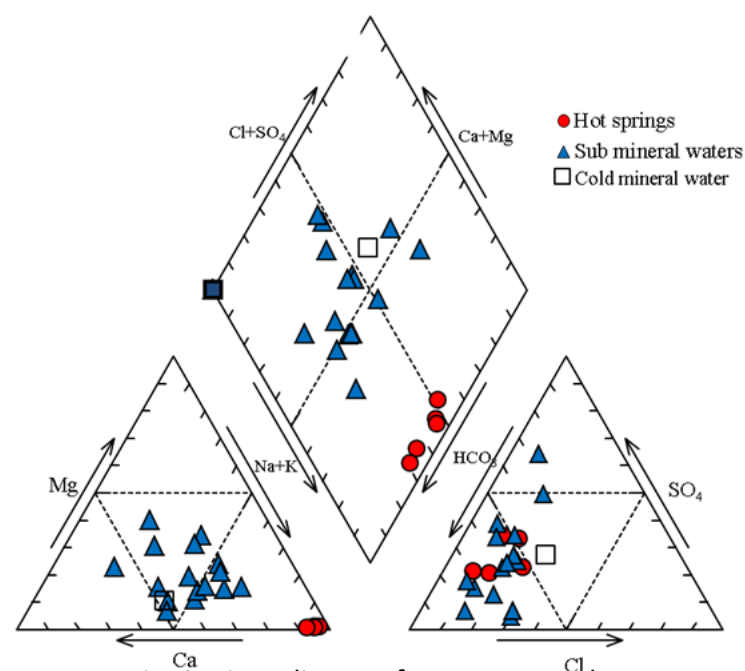

Fig. 2. Piper diagram for water samples

minerals after dolomite dissolution. This result implies that the cold springs are enriched with $\mathrm{Ca}^{2+}$, $\mathrm{Mg}^{2+}$ and $\mathrm{HCO}_{3}{ }^{-}$due to dissolution of carbonate rocks (such as dolomite), whereas all hot springs plot below the broken line. A possible explanation for the observed result is that the hot springs are enriched with $\mathrm{Na}^{+}$and $\mathrm{K}^{+}$and depleted $\mathrm{Ca}^{2+}$ and $\mathrm{Mg}^{2+}$ because of ion exchange with clay minerals in the soil resulting a higher $\mathrm{pH}$ than that of the cold spring.

Geothermometers: The results of chemical geothermometers applied to the hot springs in the Bayankhongor province are given in Table 3. These estimates were obtained using methods suggested by Fournier (1977), Arnorsson (1983), Fournier and

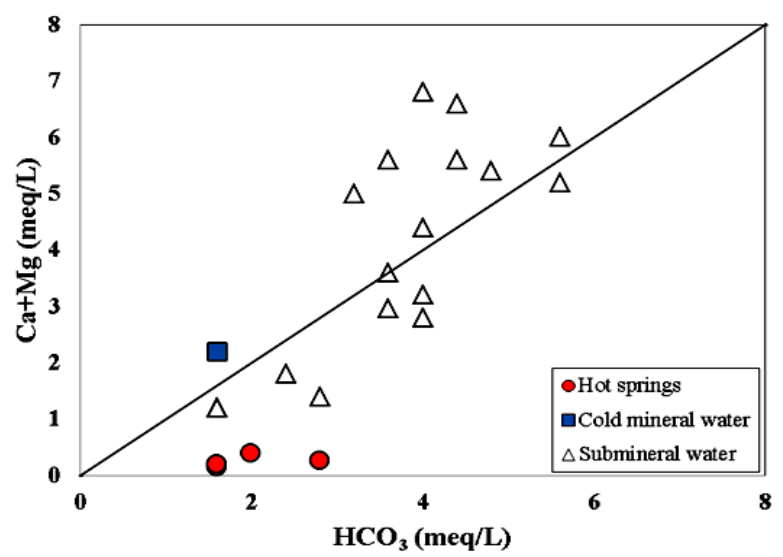

Fig. 3. The relation-ship between $\mathrm{Ca}^{2+}+\mathrm{Mg}^{2+}$ and $\mathrm{HCO}_{3}{ }^{-}$ concentrations

Truesdell (1973) and Giggenbach (1988) [1, 7, 9, 11]. The silica quartz geothermometer of Fournier (1977) [7] yielded the highest reservoir temperatures that ranges from $96^{\circ} \mathrm{C}$ to $139^{\circ} \mathrm{C}$ for all hot springs in the study area and higher than those calculated for equilibrium with chalcedony. For comparison, the 
silica-chalcedony temperature two equation proposed by Fournier (1977) and Arnorsson, (1983) $[7,1]$ gave reservoir temperature ranges from $66^{\circ} \mathrm{C}$ to $113^{\circ} \mathrm{C}$. It's obvious that the chalcedony geothermometer by Fournier (1977) [7] yields relatively similar values for all samples compared to the calibration of Arnorsson et al. (1983) [1]. The solubility of silica in thermal waters increases with an increase in temperature (Fournier, 1977 and Arnorsson, 1983) [7, 1].

Temperatures are calculated for the hot springs based on the Na-K data and using two different calibrates Table 3. The Na-K geothermometers of Arnorsson et al. (1983) [1] and Giggenbach (1988) [11] give the reservoir temperature in the range 44$93^{\circ} \mathrm{C}$ and $103-148^{\circ} \mathrm{C}$, respectively. It is obvious that the Na-K geothermometer by Giggenbach (1988) [11] yields relatively high values for all samples compared to the calibration of Arnorsson et al. (1983). The temperatures calculated (Table 3) using the $\mathrm{Na}-\mathrm{K}-\mathrm{Ca}$ geothermometer $(\beta=4 / 3)$ are similar, in the range between 87 to $121^{\circ} \mathrm{C}$ [9]. In this case, all hot springs, with an anomalous $\mathrm{Na} / \mathrm{K}$ ratio and $\mathrm{a}$ higher calculated temperature, could be the result of additional chemical reactions after mixing, including possible cation exchange reactions $[7,4,6]$. The result shows that an averaged value of calculated temperature ranges from $77^{\circ} \mathrm{C}$ to $119^{\circ} \mathrm{C}$ among the studied hot springs. These calculated reservoir temperatures also correlate well with the surface discharge temperatures of each spring and indicate low temperature geothermal resources in the study area, suggesting that these resources can be used for room heating and production of electricity by a binary system.

Table 3. Geothermometer temperatures $\left({ }^{\circ} \mathrm{C}\right)$ for hot springs in study area

\begin{tabular}{ccccccccccc}
\hline No Hot springs & $\mathrm{T}_{\text {meas }}$ & $\mathrm{T}_{\text {means }}$ & $\mathrm{T}_{\text {chal(1) }}$ & $\mathrm{T}_{\text {chal (2) }}$ & $\mathrm{T}_{\text {Ctz (3) }}$ & $\mathrm{T}_{\text {Na-K (4) }}$ & $\mathrm{T}_{\text {Na-K (5) }}$ & $\mathrm{T}_{\text {Na-K-Ca (6) }}$ \\
\hline 1 & $\begin{array}{c}\text { Ikh } \\
\text { Shargaljuut }\end{array}$ & 95 & 116 & 113 & 111 & 139 & 81 & 137 & 115 \\
2 & $\begin{array}{c}\text { Baga } \\
\text { Shargaljuut }\end{array}$ & 57 & 99 & 100 & 99 & 128 & 56 & 114 & 99 \\
3 & $\begin{array}{l}\text { Ukhug } \\
4\end{array}$ & 58 & 77 & 66 & 68 & 96 & 44 & 103 & 87 \\
5 & Teel & 32 & 90 & 81 & 81 & 110 & 56 & 113 & 98 \\
5 & Urguut & 42 & 119 & 110 & 108 & 136 & 93 & 148 & 121 \\
\hline
\end{tabular}

$\mathrm{T}_{\text {means }}$ - averaged values of calculated temperatures;

(1),(3): Fournier (1977), (2), (4): Arnórsson et al. (1983), (5): Giggenbach (1988), (6): Fournier and Truesdell (1973)

The silica-enthalpy mixing model: Truesdell and Fournier (1977) [14] proposed a plot of dissolved silica versus the enthalpy of water to estimate the temperature of the deep hot water component. Figure 4 depicts the silica-enthalpy mixing model based on chalcedony solubility and quartz solubility. The cold groundwater sample was assumed to be represented by the available data for the chemical composition of cold springs in the study area. The black line between the cold water and the mixed thermal water intersects the chalcedony solubility curve where enthalpy is equal, from 520 to $840 \mathrm{~kJ} / \mathrm{kg}$ and corresponds to the estimated reservoir temperature from 124 to $197^{\circ} \mathrm{C}$.

Subsurface temperature estimates using this method are higher than those obtained using the chalcedony geothermometer, indicating that most of the hot

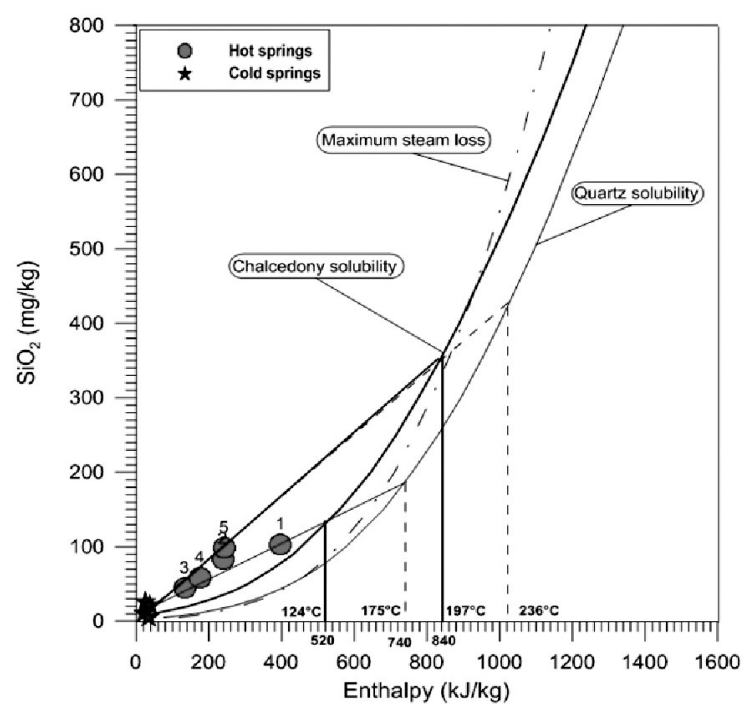

Fig. 4. The silica-enthalpy mixing model for samples from Bayankhongor province.

waters have probably mixed with cooler water in the reservoir or that conductive cooling probably took place during the up flow of the hot water. The broken line between the cold water and the mixed thermal water intersects the quartz solubility curve where the enthalpy is equal, from 740 to $1020 \mathrm{~kJ} / \mathrm{kg}$, and corresponds to the estimated reservoir temperature from 175 to $236^{\circ} \mathrm{C}$, here using the quartz geothermometer (quartz-no steam loss Fournier, 1977). The hot waters in the study area have a difference of less than $50^{\circ} \mathrm{C}$ between the measured and calculated quartz geothermometer temperatures therefore, this model is not applicable [8].

\section{CONCLUSIONS}

Hot springs, cold mineral waters and sub mineral waters in the Bayankhongor province were examined for their chemical characteristics.

The hot spring waters are belong to $\mathrm{Na}^{+}-\mathrm{HCO}_{3}-$ and $\mathrm{Na}^{+}-\mathrm{SO}_{4}{ }^{2-}$ types. All cold springs are located in two areas (northern part or mountain forest area and the southern part or Gobi desert area). TDS concentrations of cold springs of the southern part in the study area were higher than northern part's cold springs. The total dissolved silica content of cold spring were ranged from $4.5 \mathrm{mg} / \mathrm{L}$ to $26 \mathrm{mg} / \mathrm{L}$ which did not correspond to the requirements of mineral water standard of Mongolia. Therefore, these cold springs belong to the classification of sub mineral water. The cold mineral spring of Lkham belong to $\mathrm{Ca}^{2+}-\mathrm{HCO}_{3}{ }^{-}$type. The chemical composition of the sub mineral waters in the study area were characterized into four types. The sub mineral water of Uguumur 
(sample №17) belongs to $\mathrm{Ca}^{2+}-\mathrm{SO}_{4}{ }^{2-}$ type and sample №19 belongs to $\mathrm{Na}^{+}-\mathrm{SO}_{4}{ }^{2-}$ type. The sub mineral waters (sample № 7, 10, 14, 15 and 16) belong to $\mathrm{Na}^{+}$$\mathrm{HCO}_{3}$ type and other sub mineral waters belong to $\mathrm{Ca}^{2+}-\mathrm{HCO}_{3}$ type, respectively. The cold springs are enriched with $\mathrm{Ca}^{2+}, \mathrm{Mg}^{2+}$ and $\mathrm{HCO}_{3}{ }^{-}$due to the dissolution of carbonate rocks such as dolomite. The hot springs are enriched with $\mathrm{Na}^{+}$and $\mathrm{K}^{+}$due to depletion of $\mathrm{Ca}^{2+}$ by ion exchange of underlying clay minerals and become more alkaline (higher $\mathrm{pH}$ ) than that of the cold springs. The calculated equilibrium temperature ranges from $77^{\circ} \mathrm{C}$ to $119^{\circ} \mathrm{C}$ among the studied hot springs and it indicates that studied area has low temperature geothermal resources.

\section{ACKNOWLEDGEMENTS}

This research is supported by the Japan Society for the Promotion of Science (MECS-11216) (JSPS, RONPAKU; Dissertation Ph.D) Program for FY 2013. Authors wish to thank for the Administration of Bayankhongor Province for their support.

\section{REFERENCES}

1. Arnórsson S., Gunnlaugsson E., and Svavarsson H. (1983) The chemistry of geothermal waters in Iceland III. Chemical geothermometry in geothermal investigations. Geochim. Cosmochim. Acta, 47, 567-577.

2. Ariyadagva B., Dorjsuren P., Nambar B., Pissarskii B.I., Shpeizer G.M. (1980). Mineral springs and mineral lakes in Mongolia. Scientific report of Institute of Chemical and Chemical Technology, MAS. Ulaanbaatar, Mongolia, 176.

3. Bayankhongor province Statistical Office 2006 annual report: Chapter 1,Population

4. D'Amore F., Fancelli R., Caboi R. (1987) Observations of the application of chemical geothermometers to some hydrothermal systems in Sardinia. Geothermics, 16, 271-282.

5. Oyuntsetseg D., Ganchimeg D., Minjigmaa A., Ueda A., Kusakabe M. (2015) Isotopic and chemical studies of hot and cold springs in western part of Khangai Mountain region, Mongolia, for geothermal exploration. Geothermics, 53, 488-497.

6. Druschel G.K., Rosenberg P.E. (2001) Nonmagmatic fracture-controlled hydrothermal systems in the Idaho Batholith: South Fork Payette geothermal system. Chem. Geol., 173, 271-291.

7. Fournier R.O. (1977) Chemical geothermometers and mixing model for geothermal systems. Geothermics, 5, 41-50.

8. Fournier R.O. (1991) Water geothermometers applied to geothermal energy. In: D'Amore F. (coordinator), Applications of Geochemistry in Geothermal Reservoir Development. UNITAR/ UNDP publication, Rome, 37-69.

9. Fournier R.O., Truesdell A. H. (1973) An empirical $\mathrm{Na}-\mathrm{K}-\mathrm{Ca}$ geothermometer for natural waters. Geochim. Cosmochim. Acta, 37, 1255-1275.

10. Ganchimeg D., Ariyadagva B., Oyuntsetseg D. (2007) Hydrochemical study of Mineral water in Mongolia. Scientific report of Institute Chemical and Chemical Technology, MAS. Ulaanbaatar, Mongolia, 79.

11. Giggenbach W.F. (1988) Geothermal solute equilibrium. Derivation of Na-K-Mg-Ca geoindicators. Geochim. Cosmochim. Acta, 52, 2749-2765.

12. Marinov N.A. (1973). Geology of Mongolia, $2^{\text {nd }}$ ed., Nedra, Moscow (in Russian).

13. Namnandorj O, Tseren Sh, Nyamdorj O. (1966) Mineral waters of the Mongolia. First ed., Ulaanbaatar, Mongolia, 466 (in Mongolian).

14. Truesdell A.H. and Fournier R.O. (1977) Procedure for estimating the temperature of a hot water component in mixed water using a plot of dissolved silica vs. enthalpy: U.S. Geol. Survey J. Res., 5, 49-52. 